This is an electronic reprint of the original article. This reprint may differ from the original in pagination and typographic detail.

Author(s): Palttala, Pauliina; Vos, Marita

Title: $\quad$ Quality Indicators for Crisis Communication to Support Emergency Management by Public Authorities

Year: $\quad 2012$

Version:

Please cite the original version:

Palttala, P., \& Vos, M. (2012). Quality Indicators for Crisis Communication to Support Emergency Management by Public Authorities. Journal of Contingencies and Crisis Management, 20(1), 39-51. https://doi.org/10.1111/j.1468-5973.2011.00654.x

All material supplied via JYX is protected by copyright and other intellectual property rights, and duplication or sale of all or part of any of the repository collections is not permitted, except that material may be duplicated by you for your research use or educational purposes in electronic or print form. You must obtain permission for any other use. Electronic or print copies may not be offered, whether for sale or otherwise to anyone who is not an authorised user. 


\section{Quality Indicators for Crisis Communication to Support Emergency Management by Public Authorities}

Pauliina Palttala and Marita Vos, University of Jyväskylä, Finland

The purpose of this paper is to develop a framework for performance indicators to measure and improve crisis communication preparedness of public authorities. Such an instrument supporting organisational learning has not yet been developed for crisis communication. Literature is used to create a basis and the framework is derived from a process model with various phases integrating communication activities with crisis management. A strategy map is constructed clarifying how communication may contribute to crisis management by public authorities. In the paper the development of the instrument is explained and justified. Furthermore, an example of its use is provided. A next step for future research could be to analyze and compare a number of measurements.

\section{Introduction}

The paper discusses how the methodology of measuring performance indicators may facilitate continuous improvement of crisis communication quality by public organisations. By identifying strong and weak elements in the crisis communication activities, organisations can reflect on their performance and direct manpower to weak areas.

In the process of developing a crisis communication scorecard current views on crisis management and communication need to be taken into account. Crises take organisations and people by surprise, create threatening circumstances and demand a short response time from those dealing with them (Ulmer, Sellnow \& Seeger, 2007). Furthermore, crises are situations of high uncertainty in which communication aims to reduce uncertainty about response, public perception, resolution, blame and consequences (Stephens, Malone \& Bailey, 2005). Hence, crisis communication, as we understand it, can be defined as sending and receiving messages which explain the specific event, identify its probable consequences and outcomes, and provide specific harm-reducing information to affected communities in an honest, candid, prompt, accurate and complete manner (Reynolds \& Seeger, 2005; Coombs, 2007).

Crisis communication supports crisis management and is a fast growing field of study (Lehtonen, 2002). Strategically analyzing crisis situations is an important step towards excellence in crisis communication (Bradford \& Garrett, 1995), as is enabling autonomy in decision making by communication experts in organisations (Huang \& Su, 2009; Grunig, Grunig \& Dozier, 2002). Communication experts add specialist knowledge to preparedness plans, they organize training, and enhance communication with important stakeholders, e.g. 
handling media relations (Lee, Woeste \& Heath, 2007). The strategy map in a later section of this paper shows how communication can strategically contribute to crisis management.

Firstly, based on a literature review, the paper identifies the preconditions and proposes a framework for an audit instrument, a scorecard that facilitates preparedness and evaluation of crisis communication, and this way seeks to improve organisational learning. Secondly, it gives insights to the performance indicators by which efficiency can be measured. These critical factors for crisis communication have been identified by literature study and additional empirical research that have been conducted as part of the research project Developing a Crisis Communication Scorecard. This paper explains and justifies the development of the instrument and gives an example of its use in the practice.

\section{Nowadays crisis communication is strategic and continuous}

The body of knowledge on communication in organisational crisis currently stresses a context-oriented and strategic approach. Several variables affect how crises should be managed, and hence, also set requirements for crisis communication. Among these characteristics are crisis type, time phase, organisational systems and critical stakeholders (Pearson \& Mitroff, 1993). It has been emphasized (Coombs, 2006) that the chosen communication strategy should be carefully selected according to the special and unique characteristics of the ongoing crisis situation and the expectations of the stakeholders.

Currently it is understood that risk and crisis communication processes form a solid continuum, and that the two overlap in real time (Reynolds \& Seeger, 2005). Effective crisis communication must begin long before an event occurs and continue after the immediate threat has receded. This way, crisis communication covers crisis phases from pre-crisis prevention and preparation strategies and response to post-crisis containment and evaluation strategies (Fearn-Banks, 2004 in Dardis \& Haigh, 2009).

Extensive planning and preventive measures are needed for all kinds of crises, but equally important is the ability to improvise solutions for unforeseen problems that inevitably arise (Demuth, 2002). Flexibility in decision-making is crucial, as crises can have unforeseen dimensions that hinder precise decision making (Seeger, 2002). New threats may compound the risk and require a new set of communication strategies (Reynolds \& Seeger, 2005). For this reason the scorecard content should go beyond crisis-specific best practices which might be difficult to adapt in various kind of situations. Instead, the instrument should increase understanding of the quality criteria behind situation-specific experiences and this way support learning relevant to diverse situations. This line of thinking is in accordance with the best practices approach of Seeger (2006) and aims to improve mutually beneficial relationships, acknowledging the complex nature of crises and communication (Sellnow, Ulmer, Seeger and Littlefield, 2009). 


\section{A process model connects the phases of a crisis}

Crises usually follow similar chronological phases (Pearson \& Mitroff, 1993; Stephens et al., 2005). In disaster management these phases are labelled prediction, warning, emergency relief, rehabilitation (short-term), and reconstruction (long term), and the activities include mitigation, preparedness, response and recovery (Moe \& Pathranarakul, 2006).

As the literature suggests, crisis communication should be an ongoing process which carries on throughout the pre-crisis phase, the crisis situation itself, and the aftermath of the event (e.g. Ulmer et al., 2007; Coombs, 2007). Reynolds \& Seeger (2005) describe a process model of five phases (CERC, The Crisis Emergency and Risk Communication) with the following communication tasks: 1) pre-crisis risk messages and preparations to gain understanding and affect behaviour; 2) initial event uncertainty reduction and reassurance to ease emotional turmoil and add to understanding of the situation; 3) support personal response and informed decision making by the public, collect feedback and facilitate cooperation with response efforts; 4) resolution updates and discussions about rebuilding efforts; 5) evaluation and discussion of adequacy of response and consequences of lessons learned. Following this example, the scorecard specifies communication tasks for each of the disaster management phases. Later on the model has been expanded by detailed expectations of communication in different types and phases of crisis (Veil, Reynolds, Sellnow \& Seeger, 2008) and its use has been evaluated in real situations like the Hurricane Katrina and the H5N1 out brake. The assessments show that the model provides clear endorsement for planning the coordination between the responders and preparing of communication with multiple audiences in the precrisis and crisis phases, whereas for the post-crisis phases it offers a useful learning experience (Seeger, Reynolds \& Sellnow, 2009).

Falkheimer (2008) considers crises an ongoing concern in modern society and therefore questions the need to plan communication according to crisis phases. Indeed, because of the frequency of some unfortunate events a new cycle may start before the previous one is finished (e.g. pandemic flu, terrorism attacks in some places). However, specifying the phases in major disasters clarifies the tasks. And although the shifts in reality are not necessarily a linear process (Chess, 2001), linear steps in communication planning and activities are needed in order to achieve the intended results. Although in reality events may unfold in different ways, these linear steps facilitate preparing crisis plans and evaluating exercises. It is for this reason that the phases of crises management form the structure of the crisis communication scorecard. 


\section{Stakeholder-orientation guides the communication strategy}

Another principle that formed the basis of the scorecard is stakeholder orientation. Generally, the goal of communication is to enhance interaction between an organisation and its social environment. This is also called the interface function (Cheney \& Christensen, 2001). From an enactment perspective (Weick, e.g. 2001) the environment is socially created; that is, enacted through communication processes in which people read each other's behaviour and construct attributions to make sense of the situation (Sutcliffe, 2001). People make sense of events by their actions and communicate with others. But in a crisis publics experience higher levels of uncertainty which in turn hinder belief and sense-making structures (Weick, 1993). People's understanding of the world might change when a shocking event takes place. Public authorities instruct citizens how they can reduce risks and provide information about the ongoing events. The actions of citizens together with those of rescue organisations cocreate the unfolding event, and influence how the crisis evolves. Public authorities need to collect and interpret information as the crisis develops. In this way they act as 'discovering organisations' that actively gather and exchange data obtained from stakeholders to better understand the environment (Sutcliffe, 2001). Their actions represent sense-making of the situation but also sense-giving in interaction with citizens, thereby shaping the course of events. The various organisations active in crisis management enact the environment and do so in a more or less coordinated way. Most crises require information exchange within a complex response network of public and private organisations.

Instead of the former sender-receiver-focused paradigm of communication, the social environment is understood nowadays as a politicised field of forces with many senders and possibly conflicting messages competing for the attention of receivers (Vos \& Schoemaker, 2004; Sellnow et al., 2009; Tansey \& Rayner, 2009). This notion is crucial for crisis communication. On the one hand it emphasizes that the relevant authorities have to make sure they are seen as key sources in crisis situations. On the other hand it underlines the importance of expectations, information needs, and ways of information processing on the part of receivers, as these should be taken into account when planning communication activities.

An effective crisis response requires that a broad number of the stakeholders involved is recognized (Stephen et al., 2005). Generally, a stakeholder can be "any group or individual who can affect or is affected by the achievement of the organisation's objectives" (Freeman, 1984). Stakeholder theory focuses on the consequences of the interaction between an organisation and its social environment and how relationships could be better managed (Frooman, 1999). According to the resource dependence theory, stakeholders are seen as guardians of resources (Pfeffer \& Salancik, 1978). Strong stakeholder relationships are the bottom line of effective crisis communication as they may prevent breakdowns in established organisational structures (Ulmer et al., 2007). 
Yet, in crisis communication there often seems to be a lack of discourse between an organisation and its stakeholders. Attending to the various stakeholders is not enough; what is also needed is a greater stakeholder voice (Deetz, 2001). A vacuum of communication emerges when stakeholders look for necessary and relevant information which the organisation does not provide. This is compounded by speculation by the media which commonly occurs in a crisis since the information available is not consistent or is insufficient (Ulmer, Sellnow \& Seeger, 2007). In large-scale emergencies, such as natural disasters and major accidents the identification of the various stakeholder groups is a challenge for public organisations. Different stakeholders also need to be addressed by different message strategies (Stephens et al., 2005), since expectations, needs and information seeking vary.

Many organisations say they have accepted a stakeholder model, but attending to the various stakeholders is not enough as this also entails increasing stakeholder voice (Deetz, 2001). Communication has an interface function connecting the organization with the environment (Cheney \& Christensen, 2001). This works both ways. Yet, crisis communication with stakeholders has so far been mostly sender-oriented and one-way, while the importance of two-way communication between stakeholders and authorities, and the central role of communication for emergency management to affect outcomes such as selfefficacy are stressed in the literature (e.g. Veil et al, 2008). In response to criticism authorities have started to evaluate their efficiency in communicating with their stakeholders. As the relevant stakeholder groups will in any case be different in each crisis, the scorecard mentions three main stakeholder groups. For crisis communication the affected citizens and communities (e.g. families, schools and companies) can be considered the key stakeholder groups, while the news media have an intermediary role and the response organisations share a service role. In the planning of crisis communication the needs of each stakeholder group should be taken into account while allowing further crisis-specific subdivision, especially of citizen groups.

\subsection{Citizens}

For the directly and indirectly affected citizens and communities effective communication means that the response organisations are able to provide information services that meet their expectations regarding the problem in question. Huang and $\mathrm{Su}$ (2009) emphasise the need for timely, consistent and proactive information to help minimize the negative impact of the crisis.

In the crisis communication literature a human-centred perspective is emphasized, in which communication is based on analyses of what people want and need to know. Understanding and building trust aims at partnership-like relations with the public, which is considered to be one of the best practices in crisis communication (Seeger, 2006). Trust in relationships is built on open and honest communication that allows dialogue (Sellnow et al. 2009). According to Kaman Lee (2005), stakeholders form interpretative communities, and thus response organisations need to understand the mechanisms that define how 
interpretations are made regarding the event (locus of cause, crisis responsibility, impact, organisational responsibility, crisis handling). Hence, the dynamics of making sense through clarifying the situation are of paramount importance. The style of communication and the issues discussed must be determined by the public's dominant discourses (Jones, 2002). In crisis communication being aware of the needs of citizens is crucial as it directs attention to which topics should be addressed and provides feedback.

\subsection{News media}

During a crisis, organisations are obliged to provide information about the situation accurately and completely via the news media (Seeger, 2006). The news media can be subdivided into e.g. print and broadcast, as well as local, national and international media. Crisis responders pay attention to how the media portray the crisis, as it is assumed that the public perceives a crisis according to how the media frame their news stories (Choi \& Lin, 2009).

In crisis communication the mass media are considered an important and fast channel to inform the public. However, in the era of online media, internet websites, blogs and discussion forums, in particular, have gained importance as compared to the traditional print and broadcast media (Cloudman \& Hallahan, 2006). New communication technologies can turn a crisis happening anywhere into a nationwide or international news story and create discussions on the internet (Coombs, 2007). Moreover, any problem might turn into an issue or even crisis in a social media forum (Coombs, 2002). Internet requires organizations to be even more transparent and open. The news media also utilize the public's new ability to participate in reporting as an eye witness on site.

Yet the media are also seen as the 'other side' in crisis situations. In a severe emergency, journalists are generally willing to drop their critical role and cooperate with response organisations to protect the public (Allan \& Zelizer, 2004), while at a later phase of the crisis there will be a return to a more critical attitude. The scorecard should indicate how media relations can be improved in order to facilitate cooperation in crisis situations.

\subsection{Response network}

The network of organisations involved in crisis response consists of public and private organisations. Public authorities include first responders (fire department, police and hospitals), local, regional and national governmental bodies, safety authorities etc. Nongovernmental organisations include e.g. medical, development and religious organisations, while other private organisations may also be involved, such as airline and infrastructure companies.

As past crises have revealed, networking and cooperation among the range of actors is crucial (Palm \& Ramsell, 2007). In complex crises no single authority alone has the requisite competence to identify and resolve the problem for all the different sectors of society (Burkle $\&$ Hayden, 2001). Crisis operations are multiorganisational, transjuridictional, polycentric 
response networks which demand lateral control (Boin, 't Hart, Stern \& Sundelius, 2005). A special edition of the Journal of Contingencies and Crisis Management addresses why coordination in crisis management often is problematic (Helsloot, 2008). There may be a lack of consensus about what coordination is, while overall coordination, is also difficult to achieve in any disaster regardless of magnitude (Quarantelli, 1988).

Many emergencies require a response by various organisations with different ways of working which makes coordination and cooperation challenging. In terms of research, the multi-organisational networks should be examined as an entity as case studies on separate organisations provide an incomplete picture of the crisis situation (Adkins, 2010). In line with this, performance evaluation for crisis management in a network context was suggested by Abrahamsson, Hassel and Tehler (2010). Therefore, the Crisis Communication Scorecard also stimulates attention for cooperation in the response network. Organisations within the response network should be aware of and understand the network structure, ways of working and know when upscaling or downscaling between different governmental levels is needed. Organisations have different levels of expertise in communication; and, moreover, when they do not share a common organisational culture, communication may be valued and executed differently (Eisenberg \& Goodall, 1997).

\section{Towards a crisis communication scorecard}

The Balanced Scorecard of Kaplan and Norton is a measurement and improvement system designed to translate strategies into concrete actions (Buytendijk \& Brinkhuis-Slaghuis, 2000). The purpose of a scorecard is to assess quality, facilitate decisionmaking, steer strategy choices and enable learning. Balanced scorecards can be adapted to an organisation- or unitspecific instrument, tailored to the strategy of the organisation (Kaplan \& Norton, 2001 and 2004). Scorecards have been developed for specialist areas like city management (Weig, 2003) and disaster management (Moe, Gehbauer, Senitz \& Mueller, 2007). Furthermore, scorecards have been developed for various areas of expertise, such as human resource (e.g. Becker, Huselid \& Ulrich, 2001), marketing (e.g. Peelen, Waalewijn, and Wijnia, 2000), IT (e.g. Keynes, 2005), and communication (e.g. Vos \& Schoemaker, 2004; Zerfass, 2008). A scorecard for crisis communication does not yet exist.

Measurement of intangibles is considered difficult but nevertheless feasible (Hubbard, 2007). For the communication area Rolke and Koss (2005) suggest structuring performance indicators according to key objectives of communication that may serve as an umbrella for several communication activities. Performance indicators are usually measured by facts and figures already available, but for communication a range of metrics is not yet commonly used. Some authors therefore use indicators that are broader than communication itself (Ritter, 2003; Sverges Informations förening, 1996; Zerfass, 2008). This is, however, problematic as 
indicators such as market share and share price are also influenced by many other factors than communication. Performance measurement should show the added value of communication (Hering Schuppener \& Sommerhalder, 2004) and therefore it is important that the performance indicators focus on communication alone. The metrics used should be valid, reliable and of significance for the topic, as they otherwise create 'Scheingenauigkeit', a false sense of preciseness (Weig, 2003). Using already available metrics may seem efficient, but for the purpose of learning the relevance of the measures is more important.

Vos (2009) uses auditor and self-assessment where the requisite metrics are lacking. This is also used in a method of quality control developed by the European Foundation of Quality Management, EFQM (Ahaus \& Diepman, 2002). The scorecard approach can be used to provide an overview of performance indicators, while it can be complemented with measurement by assessment scales derived from quality control. This way the crisis communication scorecard consists of indicators with scales to assess communication quality.

Learning is facilitated by assessment scales derived from quality control. Edenius and Hasselbladh (2002) say that the balanced scorecard method triggers dialogue and reflection, which is positive for learning, but they criticize its use of key figures which tend to assume a life of their own. The instrument developed here uses assessment scales rather than key figures and it stresses dialogue and reflection for learning, rather than top down control. It is developed to support reflection on crisis communication preparedness and exercise evaluation.

\subsection{Strategy map}

The performance indicators of a scorecard should contribute to the strategic goals set by the organisation as a whole (Kaplan \& Norton, 2001 and 2006). This is also important for communication scorecards, as noted by Zerfass (2008). The performance indicators in the crisis communication scorecard fit the goals of crisis communication presented in the following strategy map. The map provides an example of how crisis communication goals are aligned to crisis management at the higher level (see figure 1).

The original strategy map, developed for companies by Kaplan and Norton (2004, 2006), is customized for crisis communication supporting crisis management by public organizations. Here the crisis management perspective refers to the societal goal of prevention and reduction of harm or damage. It replaces the organisation's financial perspective in the original strategy map. Whereas private organisations seek to make profit for shareholders and investors, public authorities have a mandate to serve society. Communication goals for stakeholders replace the originally mentioned goals for customers and here the citizens are emphasized as 'end users' of crisis communication. 
Figure 1. Strategy map for crisis communication supporting crisis management by public organisations

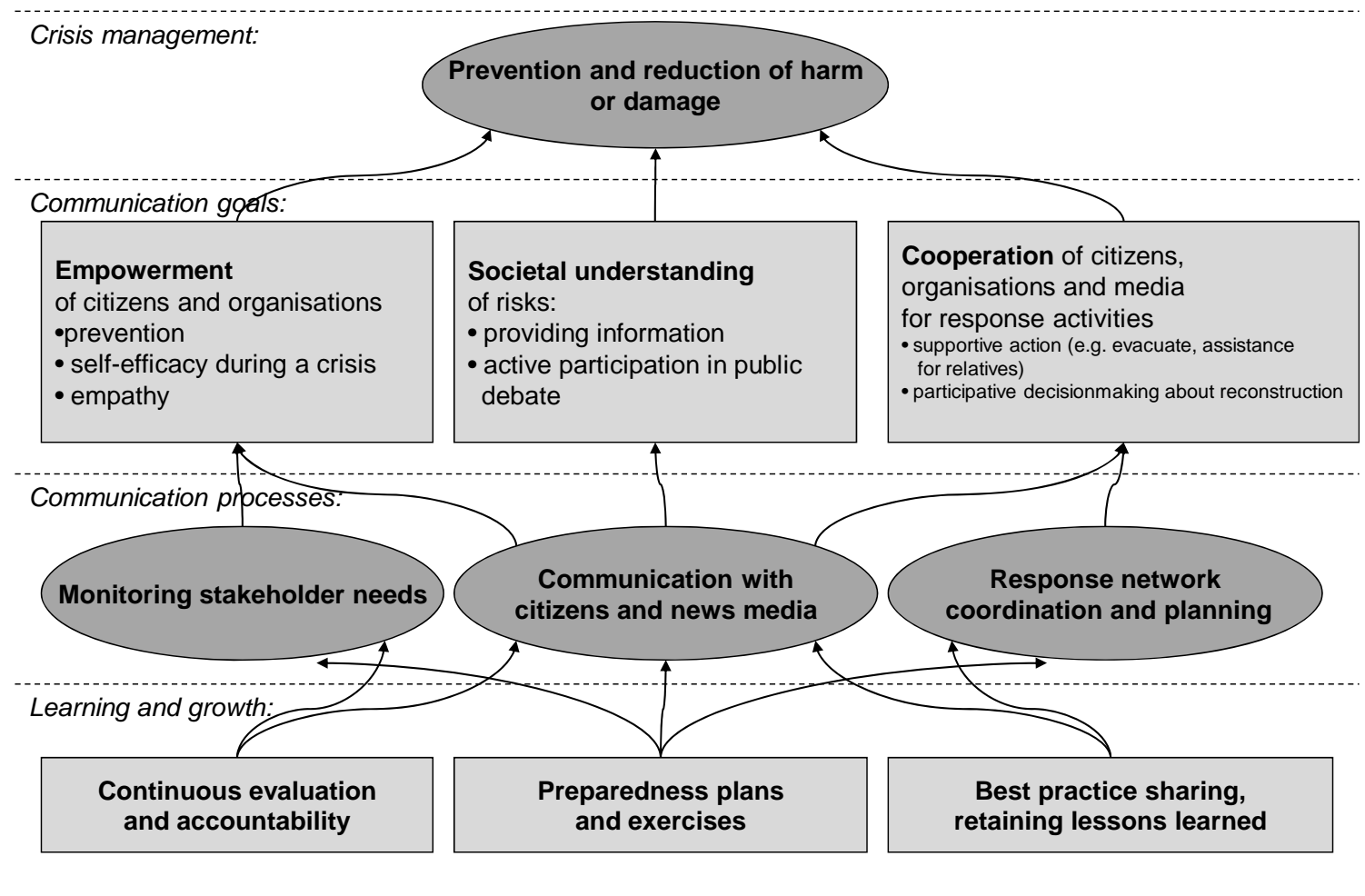

Communication contributes to crisis management by realizing strategic goals. This includes empowerment of citizens and organisations by giving instructions that increase the self-efficacy of people in managing risks for themselves and their family members or employees. Societal understanding of risks is increased by providing information and stimulating active participation in the public debate. Crisis management can be seen as a coproduction, requiring not only activities by response organisations but also the cooperation of citizens in rescue activities (e.g. notifying the authorities about suspicious packages, cooperation in evacuations), assistance for those in the neighbourhood who cannot be reached by regular information or need additional help, and participation in decision making about reconstruction activities.

As a next step the original strategy plan mentions (internal) communication processes. Those include monitoring of stakeholders' needs, communication with citizens and the news media, and exchange of information and coordination within the response network. Learning and growth follows the original model and emphasizes how performance is tenuously evaluated and developed. For learning and growth key activities of crisis communication are: continuous evaluation and accountability, creating preparedness plans and exercises, as well as sharing best practices and retaining lessons learned. This example of a strategy map shows how crisis communication may contribute to the goals of strategic crisis management. In the 
crisis communication scorecard the elements of the strategy map are integrated in a format that follows the crisis phases and the stakeholders.

\subsection{An outline for the scorecard}

Moe et al. (2007) developed a scorecard for natural disaster management projects in which the performance indicators are listed per disaster management phase in a matrix that also shows the regular fields of business scorecards: financial, customer and internal business processes, next to learning and growth. Instead, the Crisis Communication Scorecard also follows the phases of a crisis but combines these with stakeholder groups.

Scorecards are usually customized and this is also in accordance with Edenius and Hasselbladh (2002) who mention limitations of following the traditional four scorecard fields suggesting a more free approach. This way, the crisis communication scorecard is inspired by Kaplan and Norton (2001) and uses a similar methodology of performance indicators based on a strategy map, but follows a different structure of the scorecard adapted to crisis communication that emphasises the crisis phases and stakeholders.

The main elements defining the structure for the instrument are the crisis phases and the stakeholder groups (see table 1). The crisis management phases are given in the left- hand column and the stakeholders constitute the right end of the table.

Based on crisis communication literature communication tasks were clustered per crisis phase. In all, the instrument has 25 tasks that are subsequently measured by performance indicators. Performance indicators can simply be listed following e.g. Ritter (2003), but here the performance indicators are listed per task with an added explanation and references to sources that support their relevance. There is a total of 63 performance indicators: 18 for the preparation phase, 8 for the warning phase, 20 for the response phase, 12 for reconstruction phase and 5 for the evaluation phase. In practice the whole scorecard will not be used at the same time, but the preparation phase is used in a preparedness audit, while any of the later phases can be used to evaluate a crisis communication exercise. The online application directs the user through the various parts.

The performance indicators are phrased as statements which can be rated on a fixed scale. Table 1 gives some examples of indicators: "The needs and perceptions of public groups are monitored and analysed" and "Questions and misinterpretations are identified and addressed." or "Information exchange and coordination of current tasks and issues to stimulate recovery is arranged in the organisation and within the response network" and "Contacts in the organisation and with other participants in the response network are evaluated throughout the process to improve these where needed." The instrument as a whole will be available online. 
Table 1: The framework of the Crisis Communication Scorecard

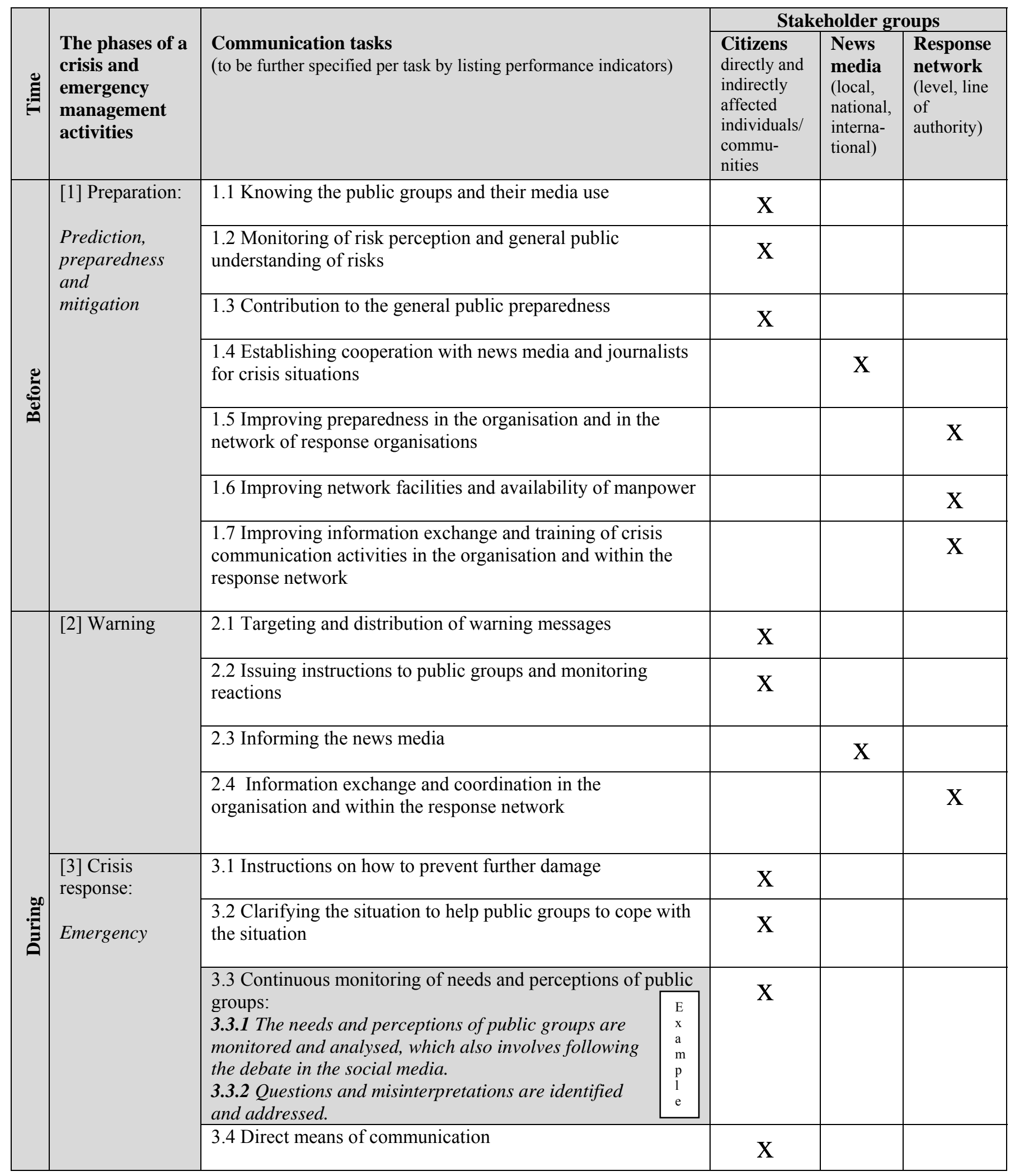




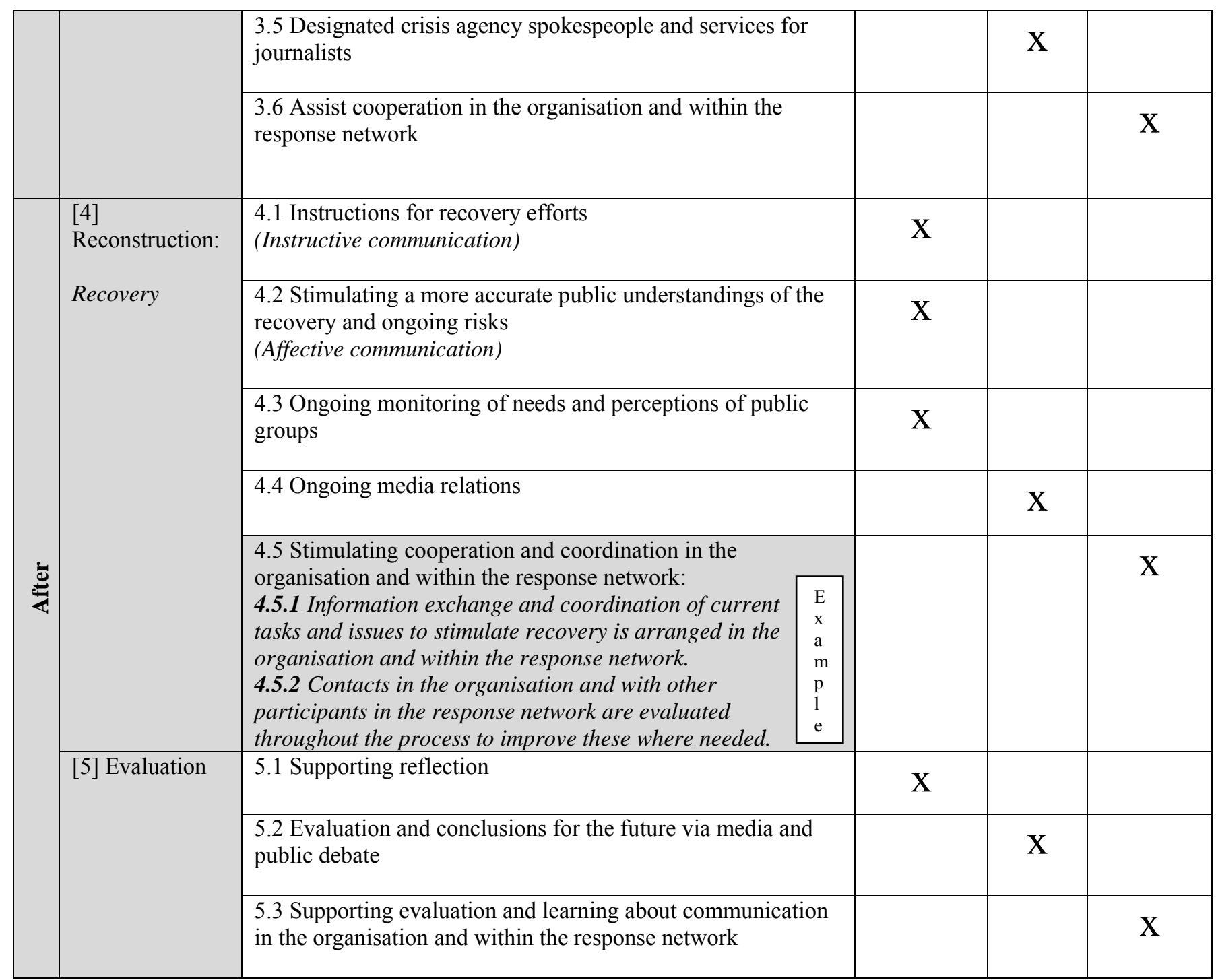

The list of performance indicators is more specified and longer than suggested by e.g. Moe et al. (2007), who list only a few measures. Thus, the scorecard of crisis communication is not just a shortlist of existing, and often not very relevant metrics, but a learning tool that indicates critical factors based on research to improve the quality of crisis communication. The performance indicators were based on up-to-date research knowledge and in the complete version sources are linked to explain them. The performance indicators were also explained for the benefit of users and help material has been provided next to the tool.

The results of performance measurement should be easy to read but also provide enough detail. Moe et al. (2007), for example, add a colour code like traffic lights to the results of the performance indicators to make the outcomes easy to interpret; unfortunately, results of their crisis management instrument have not been published. Vos (2009) analyzes strong and weak parts, as the latter need more attention. Here it is proposed to provide tables 
to compare the results for the stakeholder groups and the crisis phases, and add colour codes to highlight communication tasks needing more attention. In later years, the measurement results can be compared with previous outcomes, this way supporting continuous improvement. The approach is inspired by business scorecards but the framework and content are based on crisis communication literature.

\subsection{The use of the crisis communication scorecard}

Since crises are always a challenge to existing organisational structures, organisations need to prepare for uncertainty through simulations and training (Ulmer et al., 2007), and to be confronted with the results of their crisis communication to maintain a high level of awareness and attention to crisis demands. The scorecard motivates the crisis communication preparedness of response organisations and reveals the overall picture of how crisis communication is conducted. It is an instrument that supports communication planning and training by public authorities.

The instrument can be used for various purposes: (1) to conduct a preparedness audit and test the crisis communication plan beforehand, (2) to evaluate the communication in an exercise, and (3) to learn from what happened as a post-crisis case evaluation. To use the scorecard as an audit of crisis communication preparedness means a focus on the first phase. This includes promoting preparedness among stakeholder groups, creating communication facilities such as crisis websites, making scenario-based crisis communication plans, increasing expertise and capacity, and organising regular crisis exercises within the response network. When the scorecard is used to evaluate a crisis communication exercise the focus is on any of the later phases of a crisis, often warning and response but reconstruction and evaluation can also be the focus. During an exercise, lapses of time can be simulated that confront the actors with an evolving situation, while the roles of network partners, citizens and journalists can be arranged to create a realistic scenario. After a real crisis the communication can be assessed by auditors and the result can be discussed within the organizations involved and used for reflection in the network.

After the construction of the instrument its applicability in practice was tested in various ways (see Palttala \& Vos, 2011). To summarize, as a first step the clarity of the performance indicators was evaluated in 8 interviews with representatives of authorities in Finland and 6 international experts (scientists involved in crisis management practice and public officials in Europe). This indicated that the instrument was deemed comprehensive and usable, while some concepts used needed more explanation, and because of its length the instrument should be presented in parts per phase. The framework that combines stakeholders with different communication tasks in the crisis phases was appreciated, and the instrument was considered helpful in setting standards for crisis communication. The feedback received led to a clearer phrasing of the content and presentation of the instrument online. 
As a second step the use of the scorecard was tested (1) as a preparedness audit and (2) to evaluate a crisis exercise in the municipality of Kuopio, Finland. For the preparedness audit representatives of organizations involved in the municipal response network were invited for a meeting and asked to gather information based on the preparedness indicators. The audit was considered useful and the performance indicators clear and relevant to help point out strong and weak points, although, at some points, further clarification of the content was needed. Similar improvements occurred after observing its use to evaluate an exercise for a complex fire in the same municipality. The participants said that the instrument provided a clear framework for evaluation of the communication in the exercise, facilitating reflection. The tests showed that the instrument has potential to help identify points for improvement and evoked useful discussion about communication quality needed in crisis situations.

\subsection{The water contamination case as an example of an external audit}

Next to the tests mentioned above, the scorecard was used to evaluate the communication in a real crisis situation of water contamination of a small Finnish town. The purpose was to test the instrument for its use as an auditor assessment to facilitate learning after a real crisis case. To illustrate how the scorecard is used and how the results reveal the state of communication performance, a summary of the overall results and some examples of the audit are given here.

The water system contamination occurred in the end of 2007, when large parts of the drinking water network of the town were contaminated and clean and spoiled water were mixed. This caused an epidemic with thousands of cases of diarrhoea and vomiting primarily due to Norovirus and Campylobacter infection. Hundreds of the 12,000 inhabitants were hospitalised and the town was forced to give an order to boil all water used for human consumption and even ban all use of water at one stage. The cause for the contamination was a mistakenly opened valve between drinking water and treated waste water pipes in the waste water treatment plant. Warning and crisis communication management failed which lead to an erosion of reputation with long-lasting effects in the area.

The case audit was conducted by two external auditors and it was based on existing incident investigation documentation. The auditors were researchers who participated in the construction of the scorecard. One of them was also a member of the incident investigation board of the case and, hence, had insider knowledge compulsory for assessing performance in the organizational context. Especially, the performance of the town administration and water works were investigated.

The audit was done to learn afterwards from the case and it focused on the preparation, warning and response phases. Each communication task was evaluated by rating various performance indicators. Both auditors made individual assessments per indicator and afterwards the average scores for each indicator were marked into the scorecard. (The scores can also be based on more respondents and discussed in a reflection meeting.) The tool then 
provided total scores for tasks, crisis communication phases and stakeholder groups to facilitate finding a pattern in the results that helps interpretation.

Below the results of the case evaluation are shown, illustrating how the scorecard can help point out what needs most attention to improve the crisis communication. The results are first presented in a summary overview by the evaluated phases in this case audit (table 2). After that a closer look at the task and performance indicator levels is provided to specify the lowest scores in table 3 .

\section{Table 2. Example of a case audit water contamination: summary overview of the results per phase}

$1=$ This is completely not taken care of, 2 = The importance has been recognized, but no action is taken, $3=$ We have started to manage/act on this , $4=$ This is part of the action, but non-systematic, $5=$ This is a systematic (and expected) part of the action.

\begin{tabular}{|l|c|c|c|c|}
\hline Crisis phase: & Citizens & $\begin{array}{c}\text { News } \\
\text { media }\end{array}$ & $\begin{array}{c}\text { Response } \\
\text { network }\end{array}$ & $\begin{array}{c}\text { Average } \\
\text { scores per } \\
\text { phase }\end{array}$ \\
\hline 1. Preparation & 1,0 & 3,0 & 2,6 & $\mathbf{2 , 2}$ \\
\hline 2. Warning & 1,9 & 3,0 & 4,0 & $\mathbf{3 , 0}$ \\
\hline 3. Crisis response & 2,5 & 2,7 & 2,7 & $\mathbf{2 , 6}$ \\
\hline Overall scores per stakeholder group & $\mathbf{1 , 8}$ & $\mathbf{2 , 9}$ & $\mathbf{3 , 1}$ & \\
\hline
\end{tabular}

As shown in the table 2 communication with citizens was considered insufficient throughout the whole incident, even though some improvement was noted in later phases. One explanation to this might be that the town administration and water works had not expected and planned for such an emergency, caused by a human mistake, to occur even though it is one of national emergency scenarios. In this case, cooperation agreements required by the law existed but performance was not fully organized according to them. The town's communication plan listed some communication principles and channels, but it wasn't comprehensive and did not cover different crisis scenarios. Also the citizens of the town were not educated in how to act in the case of contaminated tap water. The early signals that indicated the problem led to some communication within the network of organizations involved, but the warning to citizens was given late and it was not coordinated among town administration, water works, health care and rescue services.

To better understand which activities contributed mostly to the low scores, the results should be dissected on the level of the communication tasks and performance indicators. In table 3 the scores for each communication task are given with some examples of poorly handled indicators. For instance, in this case the citizens were not segmented into public groups with different ways of seeking information and different needs for communication about water quality (e.g. the chronically sick, or pregnant women). Initially, the warning and the channels chosen were not effective in reaching people, while also the effect of the warning was not checked. As the crisis developed instructions to citizens became more effective. 
However, messages were informative only and apologies or background information about the cause and consequences, duration and corrections were not given. This could have eased coping with the situation. The local daily news paper was addressing many concerns of the citizens to which the town did not respond.

Table 3. Example of a case audit water contamination: more detailed results of the communication tasks. Examples of the most low-ranked tasks are opened up to the indicator level and their score are given in brackets.

1 = This is completely not taken care of, 2 = The importance has been recognized, but no action is taken, $3=$ We have started to manage/act on this , $4=$ This is part of the action, but non-systematic, $5=$ This is a systematic (and expected) part of the action.

\begin{tabular}{|c|c|c|c|c|c|}
\hline Communication task & $\begin{array}{l}\text { Nr. of } \\
\text { indicators }\end{array}$ & $\begin{array}{l}\text { Average } \\
\text { task score }\end{array}$ & Citizens & $\begin{array}{l}\text { News } \\
\text { media }\end{array}$ & $\begin{array}{l}\text { Response } \\
\text { network }\end{array}$ \\
\hline \multicolumn{6}{|l|}{ PHASE 1. PREPARATION } \\
\hline $\begin{array}{l}\text { 1.1 Knowing the public groups } \\
\text { and their media use } \\
\text { 1.1.1 The various public groups are } \\
\text { identified according to how they seek } \\
\text { and receive information about risks. (1) } \\
\text { 1.1.2 It is known which sources and } \\
\text { intermediaries the various public } \\
\text { groups consider reliable. (1) }\end{array}$ & \begin{tabular}{|l|}
2 \\
$\mathrm{E}$ \\
$\mathrm{x}$ \\
$\mathrm{a}$ \\
$\mathrm{m}$ \\
$\mathrm{p}$ \\
1 \\
$\mathrm{e}$ \\
\end{tabular} & 1,0 & $\mathrm{X}$ & & \\
\hline $\begin{array}{l}\text { 1.2 Monitoring of risk perception } \\
\text { and general public understanding } \\
\text { of risks }\end{array}$ & 1 & 1,0 & $\mathrm{X}$ & & \\
\hline $\begin{array}{l}1.3 \text { Contribution to the general } \\
\text { public preparedness }\end{array}$ & 2 & 1,0 & $\mathrm{X}$ & & \\
\hline $\begin{array}{l}\text { 1.4 Establishing cooperation with } \\
\text { news media and journalists for } \\
\text { crisis situations }\end{array}$ & 4 & 3,0 & & $\mathrm{X}$ & \\
\hline $\begin{array}{l}1.5 \text { Improving preparedness in the } \\
\text { organisation and in the network } \\
\text { of response organisations }\end{array}$ & 4 & 3,0 & & & $\mathrm{X}$ \\
\hline $\begin{array}{l}\text { 1.6 Improving facilities and the } \\
\text { availability of manpower }\end{array}$ & 2 & 1,5 & & & $\mathrm{X}$ \\
\hline $\begin{array}{l}1.7 \text { Improving information } \\
\text { exchange and training of crisis } \\
\text { communication activities in the } \\
\text { organisation and within the } \\
\text { response network }\end{array}$ & 3 & 3,3 & & & $\mathrm{X}$ \\
\hline
\end{tabular}




\begin{tabular}{|c|c|c|c|c|c|}
\hline \multicolumn{6}{|l|}{ PHASE 2. WARNING } \\
\hline $\begin{array}{l}2.1 \text { Targeting and distribution of } \\
\text { warning messages }\end{array}$ & 3 & 2,3 & $\mathrm{X}$ & & \\
\hline $\begin{array}{l}\text { 2.2 Issuing instructions to public } \\
\text { groups and monitoring reactions } \\
\text { 2.2.1 The warning messages to civil } \\
\text { public groups: are provided in a timely } \\
\text { manner and their content is well } \\
\text { checked; stand out to attract attention; } \\
\text { give clear instructions for action to } \\
\text { reduce the likelihood of harm; include } \\
\text { advice how to find more information; } \\
\text { encourage people to contact persons } \\
\text { who might not know of the warning(1) } \\
\text { 2.2.2 The effect of warning messages is } \\
\text { checked. (2) }\end{array}$ & \begin{tabular}{|l}
$\mathrm{E}$ \\
$\mathrm{x}$ \\
$\mathrm{a}$ \\
$\mathrm{m}$ \\
$\mathrm{p}$ \\
1 \\
$\mathrm{e}$
\end{tabular} & 1,5 & $\mathrm{X}$ & & \\
\hline 2.3 Informing the news media & 2 & 3,0 & & $\mathrm{X}$ & \\
\hline $\begin{array}{l}2.4 \text { Information exchange and } \\
\text { coordination in the organisation } \\
\text { and within the response network }\end{array}$ & 1 & 4,0 & & & $\mathrm{X}$ \\
\hline \multicolumn{6}{|l|}{ PHASE 3. CRISIS RESPONSE } \\
\hline $\begin{array}{l}3.1 \text { Instructions on how to prevent } \\
\text { further damage }\end{array}$ & 4 & 3,0 & $\mathrm{X}$ & & \\
\hline $\begin{array}{l}\text { 3.2 Clarifying the situation to } \\
\text { help public groups to cope with } \\
\text { the situation } \\
\text { 3.2.1 Understanding of the crisis and its } \\
\text { circumstances is increased.(1) } \\
\text { 3.2.2 Empathy with the public groups } \\
\text { affected by the crisis is shown by official } \\
\text { spokespeople. (1) } \\
\text { 3.2.3 Special attention is given to } \\
\text { provide information and support for } \\
\text { those directly affected by the emergency. } \\
\text { (1) }\end{array}$ & \begin{tabular}{|l|}
$\mathrm{E}$ \\
$\mathrm{x}$ \\
$\mathrm{a}$ \\
$\mathrm{m}$ \\
$\mathrm{p}$ \\
$\mathrm{l}$ \\
$\mathrm{e}$
\end{tabular} & 1,0 & $\mathrm{X}$ & & \\
\hline $\begin{array}{l}3.3 \text { Continuous monitoring of } \\
\text { needs and perceptions of public } \\
\text { groups }\end{array}$ & 2 & 2,0 & $\mathrm{X}$ & & \\
\hline $\begin{array}{l}\text { 3.4 Direct means of } \\
\text { communication }\end{array}$ & 2 & 4,0 & $\mathrm{X}$ & & \\
\hline $\begin{array}{l}3.5 \text { Designated crisis agency } \\
\text { spokespeople and services for } \\
\text { journalists }\end{array}$ & 6 & 2,7 & & $\mathrm{X}$ & \\
\hline $\begin{array}{l}\text { 3.6. Assist cooperation in the } \\
\text { organisation and within the } \\
\text { response network }\end{array}$ & 3 & 2,7 & & & $\mathrm{X}$ \\
\hline
\end{tabular}


The results stimulate reflection on the balance in communication with the different stakeholders and help identify tasks needing improvement. While interpreting results after an audit those communication tasks that rate fewer than 2 should get immediate attention. Scores from 2 to 4 indicate moderate performance needing further improvement. Scores over 4 posit a positive result.

\section{Conclusions}

The scorecard for crisis communication is new whereas similar evaluation instruments exist for other specialized fields like public communication and disaster management. In the paper, an integral approach to measure crisis communication is suggested that connects communication to crisis management and hence strengthens the role of communication. The tool is meant for public authorities to improve their readiness to communicate in crisis situations.

The strategy map shows how communication goals of empowerment, adding to societal understanding and facilitating cooperation of citizens, media and organisations for response activities link to the main goal of crisis management; prevention and reduction of harm and damage.

The stakeholder orientation, process model of crisis communication and literature on scorecards form the theoretical foundation of the scorecard. In complex crises the identification of the various stakeholders is important and they ought to be addressed by different message strategies since expectations, needs and ways to seek information vary. A continuous dialogue is suggested to better understand public perception. It is also know that the different phases of crisis require different kinds of communication activities that support for instance risk reduction or preventive measures, strengthen warning or motivate to reconstruction activities.

The purpose of a scorecard is to assess quality, facilitate decisionmaking, steer strategy choices and enable learning. The main elements defining the structure for this instrument are the crisis phases and the stakeholder groups. Based on crisis communication literature communication tasks were identified and clustered per crisis phase and the tasks were specified by performance indicators which enable assessment.

The crisis communication scorecard model presented here serves planning and training purposes for crisis communication. Divided in three parts, the scorecard can be used (1) to conduct a preparedness audit and test the crisis communication plan beforehand, (2) to evaluate communication in a preparedness exercise or in an actual crisis situation, and (3) to learn from what happened as a post-crisis evaluation.

The scorecard and its content have been tested in different kinds of pilots. These showed that the tool has good potential. The framework that combines stakeholders with 
different communication tasks in the crisis phases was appreciated, and the instrument was considered helpful in setting standards for crisis communication. As an example, a water contamination case was used to show how the evaluation is conducted and how the results can be interpreted. A next step in future research could be to analyze and compare a number of measurements.

There are no other crisis communication scorecard methods published, so far, that allow for a comparison and just one publication showing measurement results of a municipal communication scorecard, in which the method is considered to facilitate reflection and learning, pointing out weak elements that need improvement (Vos, 2009). Clearly, the area of performance measurement for crisis communication needs development. This may be a promising research direction leading to further clarification and strengthening of the role of communication supporting crisis management.

\section{Acknowledgements}

The research project leading to these results has received funding from the European Community's Seventh Framework Programme (FP7/2007-2011) under grant agreement $n^{\circ}$ 217889.

\section{References}

Abrahamsson, M., Hassel, H. and Tehler, H. (2010), 'Towards a System-Oriented Framework for Analysing and Evaluating Emergency Response', Journal of Contingencies and Crisis Management, Volume 18, Number 1, pp. 14-25.

Adkins, G. (2010), 'Organizational networks in disaster response: An examination of the US government network's efforts in hurricane Katrina', in Coombs, W.T. and Holladay, S. J. (Eds.), The handbook of crisis communication, Blackwell Publishing, Boston, pp. 93-114.

Ahaus, C. and Diepman, F. (Eds.) (2002), Balanced scorecard \& Model Nederlandse kwaliteit, Kluwer, Deventer.

Allan, S. and Zelizer, B. (2004), 'Rules of engagement: journalism and war', in Allan, S. and Zelizer, B. (Eds.) Reporting war: Journalism in wartime, Routledge, New York, pp. 321.

Becker, B., Huselid, M. and Ulrich, D. (2001), The HR-scorecard; linking people, strategy and performance, Harvard Business School Press, Boston.

Boin, A., 't Hart P., Stern, E. and Sundelius B. (2005), The politics of crisis management, Public Leadership under Pressure, Cambridge University Press, Cambridge. 
Bradford, J.L. and Garrett, D.E. (1995), 'The effectiveness of corporate communicative responses to accusations of unethical behaviour', Journal of Business Ethics, Volume 14, Number 11, pp. 875-892.

Burkle, H. M. and Hayden, R. (2001), 'The concept of assisted management of large-scale disasters by horizontal organisation', Prehospital and Disaster Medicine, Volume 16, Number 3, pp. 87-96.

Buytendijk, F. and Brinkhuis-Slaghuis, J. (2000), Balanced scorecard; van meten naar managen, Samsom, Deventer.

Cheney, G. and Christensen, L. (2001), 'Organizational identity: linkages between internal and external communication', in Jablin, F. and Putnam, L. (Eds.), The new handbook of organizational communication; advances in theory, research and methods, London, Sage, pp. 231-270.

Choi, Y. and Lin, Y-H. (2009), 'Consumer response to crisis: Exploring the concept of involvement in Mattel product recalls', Public Relations Review, Volume 35, pp. 1822

Chess, C. (2001), 'Organisational Theory and the Stages of Risk Communication', Risk Analysis, Volume 21, Number 1, pp. 179-188.

Cloudman, R. and Hallahan, K. (2006), 'Crisis communicators preparedness among U.S. organisations: Activities and assessments by public relations practitioners', Public Relations Review, Volume 32, pp. 367-376.

Coombs, W.T. (2002), Assessing online issue threats: Issue contagions and their effect on issue priorisation. Journal of Public Affairs, Volume 2, Number 4, pp. 215-229.

Coombs, W.T. (2006), 'The proactive powers of crisis response strategies: Managing reputational assests during a crisis', Journal of Promotion Management, Volume, 12 pp. 241-259

Coombs, W.T. (2007), Ongoing crisis communication: Planning, Managing, and Responding, Sage, Thousand Oaks, CA.

Dardis F. and Haigh M. (2009), 'Prescribing versus describing: testing image restoration strategies in a crisis situation', Corporate Communications: An International Journal, Volume 4, Number 1, pp. 101-118

Deetz, S. (2001), 'Conceptual foundations', in Jablin, F. and Putnam L. (Eds.), The new handbook of organizational communication; advances in theory, research and methods, Sage, London, pp. 3-46.

Demuth, J. (2002), Countering Terrorism: Lessons Learned from Natural and Technological Disasters. National Academy of Sciences, http://www.nap.edu/catalog/10414.html (accessed 1 May 2010)

Edenius, M. and Hasselbladh (2002), H., The balanced Scorecard as an Intellectual Technology. Organization, Vol. 9, No. 2, pp. 249-273. 
Eisenberg, E. M. and Goodall, H. L. (1997), Organisational communication: balancing creativity and constraint, St.Martin's Press, Boston (Mass.)

Falkheimer, J. (2008), 'Glocalizing Public Relations and crisis communication: bridging gaps of trust in multicultural societies', in Zerfass, A., Ruler, B. and van Sriramesh, K. (Eds.), Public relations research: European and international perspectives and innovations, VS Verlag Fur Sozialwissenschaften, Wiesbaden, pp. 293-304.

Freeman, R. (1984), Strategic Management: A stakeholder approach, Pitman, Boston.

Frooman, J. (1999), 'Stakeholder influence strategies', Academy of management review, Volume 24 pp.191-205.

Grunig, J.E., Grunig, L.A. and Dozier, D.M. (2002), Excellent public relations and effective organisations: A study of communication management in three countries, Lawrence Erlbaum Associates, Inc., Mahwah, NJ.

Hering, R., Schuppener, B. and Sommerhalder, M. (2004), Die Communication Scorecard; eine neue methode des Kommunikationsmanagements, Haupt, Bern.

Helsloot, I. (2008), 'Coordination is a prerequisite for good collaboration, isn't it?', Journal of Contingencies and Crisis Management, Volume 16, Number 4, pp.173-176.

Huang, Y-H. and Su, S-H. (2009), 'Determinants of consistent, timely, and active responses in corporate crises', Public Relations Review, Volume 35, pp. 7-17.

Hubbard, D. (2007), How to measure anything; finding the value of intangibles in business, Wiley, Hoboken NJ.

Jones, R. (2002), 'Challenges to the notion of publics in public relations: implications of the risk society for the discipline', Public Relations Review, Volume 28, pp. 49-62.

Kaman Lee, B. (2005),'Crisis, culture, community', in Kalbfleisch, P. (Ed), Communication Yearbook, Volume 29, pp. 275-309, Lawrence Erlbaum Associates, Mahwah New Jersey.

Kaplan, R. and Norton, D. (2001), The strategy-focused organisation, Harvard Business School Press, Boston.

Kaplan, R. and Norton, D. (2004), 'Measuring the strategic readiness of intangible assets', Harvard Business Review, Volume 82, Number 2, pp. 53-63.

Kaplan, R. and Norton, D. (2006), Alignment; using the balanced scorecard to create corporate synergie, Harvard Business School Press, Boston.

Keyes, J. (2005), Implementing the IT Balanced Scorecard. Auerbach, Boca Raton.

Lee, J., Woeste, J. H and Heath, R.L. (2007), 'Getting ready for crises; strategic excellence', Public Relations review, Volume 33, pp. 334-336.

Lehtonen J. (2002), Julkisuuden riskit, Mainostajien Liitto, Helsinki.

Moe, T. and Pathranarakul, P. (2006). 'An integrated approach to natural disaster management. Public project management and its critical success factors'. Disaster prevention and management, Volume 15, Number 3, pp. 396 - 413. 
Moe, T., Gehbauer, F., Senitz, S. and Mueller, M. (2007), 'Balanced scorecard for natural disaster management projects', Disaster prevention and management, Volume 16, Number 5, pp. $785-806$.

Palm J. and Ramsell E. (2007), 'Developing local emergency management by co-ordination between municipalities in policy networks: Experiences form Sweden'. Journal of Contingencies and Crisis Management, Volume 15, Number 4, pp. 173-182.

Palttala, P. and Vos, M. (2011), Testing a methodology to improve organizational learning about crisis communication. Journal of Communication Management, Vol. 15, No. 4 (E).

Pearson, C. and Mitroff, I. (1993), 'From crisis prone to crisis prepared: a framework for crisis management', Academy of management executive, Volume 7, Number 1, pp. 48 - 59.

Peelen, E., Waalewijn, P. and S. Wijnia (2000), Marketing balanced scorecard, Samsom, Deventer.

Pfeffer, J. and Salancik, G. (1978), The external control of organisations: A resource dependence perspective, Harper \& Row, New York.

Quarantelli, E.L. (1988), 'Disaster crisis management: A summary of research findings', Journal of Management Studies, Volume 25, Number 4, pp. 373-385.

Reynolds, B. and Seeger, M. (2005), 'Crisis and emergency risk communication as an integrative model', Journal of health communication, Volume 10, pp 43-55.

Ritter, M. (2003), 'The use of balanced scorecard in the strategic management of corporate communications', Corporate communications, Volume 8, Number 1, pp. 44-59.

Rolke, L. and Koss, F. (2005), Value Corporate Communications; wie sich Unternehmenskommunikation wertorientierd managen lässt, BoD, Norderstedt.

Seeger, M.W. (2002), 'Chaos and crisis: Propositions for a general theory of crisis communication', Public Relations Review, Volume 28, pp. 329-337.

Seeger, M. (2006), 'Best practices in crisis communication: An expert panel process', Journal of Applied Communication Research, Volume 34, Number 3, pp. 232-244.

Seeger, M.W., Reynolds, B. and Sellnow, T. L. (2009), 'Crisis and emergency risk communication in health contexts: Applying the CDC model to pandemic influenza', in Heath, R.L. and O'Hair, D.H. (Eds.) Handbook of risk and crisis communication, New York, Routledge Taylor \& Francis Group, pp. 493 -506.

Sellnow, T.L., Ulmer, R.R., Seeger, M.W. and Littlefield, R.S. (2009) Effective risk communication. A message-centered approach, Springer Science + Business Media, New York.

Sverges Informations Förening (1996), Return on Communications, The Swedish Public Relations Association, Stockholm.

Stephens, K. K., Malone, P. C. and Bailey, C.M. (2005), 'Communicating with stakeholders during crisis', Journal of Business Communication, Volume 42, pp. 390-419.i 
Sutcliffe, K. (2001), 'Organizational environments and organizational information processing', in Jablin, F. and L. Putnam, The new handbook of organizational communication; advances in theory, research and methods, London, Sage, pp. 197-230.

Ulmer, R., Sellnow, T. and Seeger, M. (2007), Effective crisis communication. Moving from crisis to opportunity, Sage Publications, Thousand Oaks.

Tansey, J. and Rayner, S. (2009), 'Cultural theory and risk', in Heath, R.L and O'Hair, H.D. (Eds.), Handbook of risk and crisis communication, Routledge Taylor \& Francis Group, New York, pp. 53-79.

Veil, B., Reynolds, B, Sellnow, T. and Seeger, M. (2008), CERC as a theoretical Framework for Research and Practice. Health Promotion Practice, Volume 9, Number 4, pp. 26S$34 \mathrm{~S}$.

Vos, M. (2009), 'Communication quality and added value: a measurement instrument for municipalities', Journal of Communication Management, Volume 13, Issue 4, pp, 362377.

Vos, M. and Schoemaker, H. (2004), Accountability of communication management: A balanced scorecard for communication quality, Boom Onderwijs/ Lemma, Amsterdam.

Weick, K.E. (1993), 'The collapse of sensemaking in organisations: The Mann Gulch disaster', Administrative Science Quarterly, Volume 38, pp. 628-652.

Weick, K. (2001), Making sense of the organisation. Blackwell, Oxford.

Weig, F. (2003), Balanced Scorecard für Strategisches Management von Städten; ein Ansatz unter Einsatz von internetumfragen, VS Verlag für Socialwissenschaften, Wiesbaden.

Zerfass, A. (2008), 'The corporate communication scorecard; a framework for managing and evaluating communication strategies', in Van Ruler, B., Verčič, A.T. and Verčič, D., Public Relations Metrics; Research and Evaluation. Routledge, New York, pp.139153. 